\title{
Genotype $x$ environment interaction of agronomic and processing quality traits in potato
}

\author{
Lizete Augustin'; Sandra Milach²; Dilson Antônio Bisognin ${ }^{3}$; Marilei Suzin ${ }^{1}$ \\ ${ }^{1}$ UPF-FAMV, C. Postal 611, 99001-970 Passo Fundo-RS; augustin@upf.br; ${ }^{2}$ Pionner Sementes Ltda; ${ }^{3}$ UFSM, Camobi, $97105-900$ Santa \\ Maria-RS
}

\begin{abstract}
At the main crop production region of Rio Grande do Sul state, Brazil, potato is cultivated in two different growing seasons: autumn and spring. The objectives of this research paper were: i) identify potato clones with high yield potential and industrial quality for Autumn and Spring growing seasons in the northern/northeastern region of the state; ii) estimate the effects of environment and of the genotype $\mathrm{x}$ environment interaction on the expression of agronomic and processing quality traits of potato clones in order to determine the appropriate strategy for breeding potato for the target region. One hundred and seventy clones of nine families were developed and compared to the cultivars Atlantic, Baronesa, Catucha, Ciclamen, Hertha, Lady Roseta, Macaca, Monalisa and Vivaldi and to the clone SMIJ 461-1, in the autumn and spring of 2006, in Passo Fundo, northern Rio Grande do Sul state. The evaluated traits included number of tubers per plant, tuber weight, plant yield, presence of deep eyes, dry matter content and chip color. Genotype x environment interaction $(\mathrm{G} \times \mathrm{E})$ was significant for the expression of all traits but processing quality traits like chip color were most influenced by the growing season conditions. Genetic potential expression for yield traits was maximized in the spring season. Superior clones combining agronomic and quality traits were identified at the two growing seasons. High correlation between the two growing seasons was observed for the presence of deep eyes and dry matter, indicating they can be selected at either season.
\end{abstract}

Keywords: Solanum tuberosum, industrial quality, chips color, potato cultivars.

\section{RESUMO}

Interação genótipo $\mathrm{x}$ ambiente em caracteres agronômicos e qualidade de processamento em batata

Nas principais regiões produtoras do Rio Grande do Sul a batata é cultivada em dois períodos do ano: na primavera, sob condições de fotoperíodo e temperatura crescentes e, no outono, sob fotoperíodo e temperatura decrescentes. Devido às diferenças nas condições de cultivo nessas duas épocas, é fundamental a avaliação e a identificação de clones adaptados a ambas. Os objetivos do trabalho foram: i) identificar clones com alto potencial produtivo e com qualidade industrial para as condições de cultivo de outono e de primavera na região norte/nordeste do RS; ii) estimar os efeitos da interação genótipo x ambiente e de ambiente na expressão dos caracteres agronômicos e de qualidade de processamento, visando estabelecer a melhor estratégia para o melhoramento. Nesse trabalho, 170 clones de nove famílias clonais foram desenvolvidos e comparados às cultivares Atlantic, Baronesa, Catucha, Ciclamen, Hertha, Lady Roseta, Macaca, Monalisa e Vivaldi e, ao clone SMIJ 461-1, no outono e na primavera de 2006, em Passo Fundo, região norte do Rio Grande do Sul. Os caracteres avaliados foram número de tubérculos por planta, massa fresca média de tubérculos, produtividade por planta, profundidade dos olhos, teor de massa seca e coloração dos chips. Foi observada interação genótipo $\mathrm{x}$ ambiente significativa para todos os caracteres sendo os caracteres de qualidade de processamento, principalmente coloração dos chips, mais influenciados pela época de cultivo. A expressão do potencial genético dos clones, para os caracteres relacionados à produção, foi maximizada na primavera. Foi possível identificar clones que expressaram caracteres superiores nos dois cultivos. Os caracteres profundidade de olhos e massa seca apresentaram alta correlação entre as duas épocas de cultivo, podendo ser selecionados tanto no outono quanto na primavera.

Palavras-chave: Solanum tuberosum, qualidade industrial, coloração de chips, cultivares de batata.

(Recebido para publicação em 4 de maio de 2010; aceito em 13 de dezembro de 2011) (Received on May 4, 2010; accepted on December 13, 2011)

$\mathrm{P}_{\mathrm{t}}$ otato (Solanum tuberosum) is among the most consumed foods in the world because of its high nutritional value. Potato is a rich source of protein, energy, vitamins and minerals, and presents technological and gastronomic versatility (Dale \& Mackay, 1994; Coelho et al., 1999).

The industrialization in some regions of Rio Grande do Sul state
(RS), Brazil, can benefit various stages of the production process and improve commercialization. The main advantage of industrialization is the possibility of producing tubers year round, eliminating the necessity of storage (Popp, 2000). However, the potato industry demands potatoes with specific features that provide the production with high quality and minimal losses, ie, low content of reducing sugars, high dry matter, round or oval shapes with shallow eyes (Pereira, 2003; Andreu, 2006).

In the main producing regions of Rio Grande do Sul, potato is cultivated twice during the year: i) spring, under conditions of increasing photoperiod and temperature, and ii) autumn , under decreasing photoperiod and temperature. In long-day conditions, 
plants intercept more light than in short days and, consequently, the production of photoassimilates is higher. At low light intensity, the leaf growth is stimulated at the expense of the tuber growth. Therefore, all these factors influence the physiology of the plant, changing the productive potential and the quality of the tubers (Souza, 2003; Andreu, 2005; Bisognin, 2006; Bisognin \& Streck, 2009). Research works carried out in Rio Grande do Sul state with the evaluation of production characteristics and/or processing quality in the two growing seasons (spring and autumn), reported the influence of the season on the expression of those characteristics (Rodrigues \& Pereira, 2003; Zorzella et al., 2003; Freitas et al., 2006).

The objectives of this study were: i) identify potato clones with high yield potential and processing quality under the growing conditions of autumn and spring in the northern/northeastern Rio Grande do Sul, ii) estimate the effects of the environment and of the genotype $\mathrm{x}$ environment interaction in the expression of agronomic traits and of the processing quality characteristics, aiming to determine the best strategy for the breeding of this species in the region of interest.

\section{MATERIAL AND METHODS}

The research work was carried out at the experimental field of the Faculdade de Agronomia e Medicina Veterinária of the Universidade de Passo Fundo (UPF- FAMV), in the physiographic region of the Planalto Médio $\left(28^{\circ} 15^{\prime} \mathrm{S}\right.$, $52^{\circ} 24^{\prime} \mathrm{W}$, altitude of approximately 700 $\mathrm{m})$. The experiment was carried out in 2006 during spring and autumn in an irrigated area with clayey typical Oxisol.

To obtain the clones, simple crosses involving nine cultivars and the clone SMIJ461-1 (developed at the Universidade Federal de Santa Maria) were carried out at a laboratório of UPF, in 2004. Botanical seeds of these crosses were sown in vitro and the seedlings were planted in a greenhouse for the production of mini-tubers. This material was multiplied in field in the spring of 2005. For this experiment, planting of autumn was held on March $1^{\text {st }}, 2006$ and the harvest was carried out in June $14^{\text {th }}, 2006$. The planting of spring was held on September $18^{\text {th }}$, 2006 and the harvest was carried out on January $9^{\text {th }}$ and $10^{\text {th }}, 2007$. The whole process of opening the furrows, planting and harvesting were manual and followed the recommendations of cultivation techniques for potatoes, including applications of fungicides and insecticides (Bisognin, 1996). In the autumn , fertilization was carried out in line with $100 \mathrm{~g} \mathrm{~m}^{-1}$ of NPK 5-30-15. In the spring, fertilization consisted of 100 $\mathrm{g} \mathrm{m}^{-1}$ of NPK 16-16-16. Ten days before the harvest, a herbicide pulverization was carried out in order to promote the drying of the aboveground part. The tubers were collected, bagged and stored for 20 days at room temperature before they were evaluated.

We evaluated 170 clones obtained from the crosses carried out in 2004. The experimental design was randomized blocks with three replications. The control treatments were the cultivars Atlantic, Baronesa, Catucha, Ciclamen, Hertha, Lady Roseta, Macaca, Monalisa, Vivaldi and the clone SMIJ461-1. Each plot consisted of a line with five holes, spaced $0.20 \mathrm{~m}$ from each other. The space between lines was $0.80 \mathrm{~m}$. The analyzed agronomic traits were: a) average number of tubers per plant, obtained by counting the tubers with a diameter higher than $25 \mathrm{~mm}, \mathrm{~b}$ ) fresh weight of tubers, obtained by the ratio between total production and the number of tubers larger than $25 \mathrm{~mm}$ in diameter, c) yield per plant, determined by multiplying the number of tubers per plant by the average fresh weight of tubers, d) depth of eyes, assessed using a scale where $1=$ shallow eyes, $2=$ semisuperficial, 3= medium depth, 4= deep, $5=$ very deep. The data were submitted to variance analysis and differences between means were compared by the Tukey test at 5\%.

Analyses related to the product processing quality were carried out at the Centro de Pesquisa em Alimentos (CEPA) of the Universidade de Passo Fundo (UPF). All the clones and control cultivars were evaluated and the cultivar Atlantic was used as a reference standard of quality for processing. The content of dry matter (MS) was determined according to AOAC (1980), similar to the methodology used by Freitas et al. (2006). We used two tubers from each replication collected in the field, corresponding to six tubers per clone. They were cut into small cubes, placed in aluminum mortars $(8.0 \mathrm{~g})$ for determination of the fresh weight. Afterwards, they were dried in an oven at $60^{\circ} \mathrm{C}$ until constant dry weight. Each sample was processed in duplicates. The percentage of dry mass was calculated using the formula $\% \mathrm{MS}=$ (final mass $/$ initial mass) $x 100$.

To evaluate the color, samples of each clone were processed in the form of chips. Three healthy tubers were selected at random, uniform in size, which were processed in a vegetable cutter in transverse slices 1-2 mm thick. The largest slices, which corresponded to the central part of the tuber, were fried in hydrogenated vegetable fat at $180^{\circ} \mathrm{C}$ until the production of bubbles ceased. The chip color was determined by a diffuse reflectance spectrophotometer (Hunter Lab), model ColorQuest II. In the Hunter color system, the values $\mathrm{L}^{*}$ (lightness) range between zero (black) and 100 (white), -a* (green) to $+\mathrm{a}^{*}$ (red) and $-b^{*}$ (blue) to $+b^{*}$ (yellow). The chips were placed under the reader and the readings were carried out in three replications (three chips) and two positions (center and edge). The result of the analysis corresponded to the average values between the readings of the center and the margin.

The data of dry mass and chip color were subjected to analysis of variance and means were compared by Tukey at $5 \%$.

To better visualize the performance of the families in both cropping seasons and, also, the genotype $\mathrm{x}$ environment interaction, data on plant productivity and depth of eyes were plotted in scatter plots, and the averages in the autumn were plotted on the $\mathrm{X}$ axis and the averages in the spring were plotted on the $\mathrm{Y}$ axis. The chart was divided into quadrants according to the mean in the two cropping seasons. Also, a Pearson's correlation analysis was carried out for all traits between the cultivation periods of autumn and spring. 


\section{RESULTS AND DISCUSSION}

There were significant differences $(p>0.01)$ between clones, growing seasons, families and family $\mathrm{x}$ season interaction for number of tubers per plant, average fresh weight of tubers, productivity per plant and depth of eyes, with coefficients of variation that ranged from 28.1 to 35.6 (Table 1). Coefficients of variation relatively high for production traits were also observed in similar research works due to the reduced number of tubers produced in the initial clonal generations that limit the size of the experimental plot (Bearzoti et al., 1997; Andreu, 2005).

The overall average for number of tubers per plant was 5.56 in the autumn and of 10.00 in the spring, showing the great influence of the environment for this trait (Table 1). The best yields of potatoes have been observed in regions of long photoperiods and average temperatures $\left(15-20^{\circ} \mathrm{C}\right)$ during the growing season (Souza, 2003). Factors such as temperature and number of hours of solar radiation influence the daily production through photosynthesis, crop respiration level and the proportion of assimilates transported to the tubers (Van der Zaag \& Burton apud Souza, 2003). Under the Brazilian conditions, the longer the period of the tuber growth, the greater the tuber yield (Bisognin \& Streck, 2009).

The cultivar Ciclamen presented the highest number of tubers in the two cropping seasons. However, the difference was statistically different from 'Monalisa' only in the autumn and from 'Baronesa' only in the spring
(Table 1). Considering the two seasons, the best control treatments, following 'Ciclamen', was the clone SMIJ461-1, whereas the cultivar Baronesa produced the lowest number of tubers. The family X4 (Vivaldi x Macaca) presented the highest average number of tubers per plant in both seasons, followed by the X10 family (SMIJ461-1 x Atlantic). The lowest average was presented by the family X5 (Baronesa x Vivaldi).

For the average fresh weight of tubers, the overall mean was 61.16 $\mathrm{g}$ in the autumn and $77.40 \mathrm{~g}$ in the spring (Table 1). The cultivar Atlantic presented the highest fresh weight in both seasons. In the autumn significant differences between 'Atlantic' and the control cultivars Ciclamen and Macaca were detected. In the spring, the cultivar Atlantic overcame the family $\mathrm{X} 4$ and the other control cultivars, except

Table 1. Average number of tubers per plant (tub/plant), tuber weight (MFMT), plant yield (prod/plant) and eye depth (PO) of nine families and ten controls in autumn (aut) and spring (spr) growing seasons (número médio de tubérculos por planta (tub/plant), massa fresca média de tubérculo (MFMT), produtividade por planta (prod/plant) e profundidade de olhos (PO) das nove famílias e das dez testemunhas de batata, no cultivo de outono (aut) e primavera (spr)). Passo Fundo, UPF, 2006/2007.

\begin{tabular}{|c|c|c|c|c|c|c|c|c|}
\hline \multirow{2}{*}{$\begin{array}{l}\text { Families and } \\
\text { controls }\end{array}$} & \multicolumn{2}{|c|}{ Tub/plant $\left(n^{0}\right)$} & \multicolumn{2}{|c|}{ MFMT (g) } & \multicolumn{2}{|c|}{ Prod/plant (g) } & \multicolumn{2}{|c|}{$\mathbf{P O}^{1}$} \\
\hline & aut & spr & aut & spr & aut & spr & aut & spr \\
\hline Ciclamen & $8.56 \mathrm{a}$ & $14.83 a$ & $* 37.75 \mathrm{~b}$ & $51.18 \mathrm{~b}$ & *318.12ab & $758.4 \mathrm{ab}$ & $2.0 \mathrm{a}$ & $2.0 \mathrm{abc}$ \\
\hline $\mathrm{X} 4$ & $* 6.56 \mathrm{ab}$ & $13.41 \mathrm{ab}$ & $52.91 \mathrm{ab}$ & $56.64 \mathrm{~b}$ & $320.27 \mathrm{ab}$ & $665.1 \mathrm{ab}$ & $1.8 \mathrm{a}$ & $1.6 \mathrm{bc}$ \\
\hline Lady Roseta & $6.40 \mathrm{ab}$ & $9.00 \mathrm{ab}$ & $52.89 \mathrm{ab}$ & $69.25 \mathrm{~b}$ & $333.9 \mathrm{ab}$ & $634.6 \mathrm{ab}$ & $3.0 \mathrm{a}$ & $3.3 \mathrm{a}$ \\
\hline SMIJ461-1 & $6.36 \mathrm{ab}$ & $14.13 \mathrm{a}$ & $79.20 \mathrm{ab}$ & 71.94ab & $* 487.49 \mathrm{a}$ & $1012.0 \mathrm{a}$ & $2.3 \mathrm{a}$ & $2.0 \mathrm{abc}$ \\
\hline $\mathrm{X} 2$ & $* 6.14 \mathrm{ab}$ & $9.67 \mathrm{ab}$ & $* 65.13 \mathrm{ab}$ & $81.53 \mathrm{ab}$ & $* 381.2 \mathrm{ab}$ & $748.8 \mathrm{ab}$ & $2.5 \mathrm{a}$ & $2.6 \mathrm{ab}$ \\
\hline $\mathrm{X} 11$ & $* 5.77 \mathrm{ab}$ & $9.49 \mathrm{ab}$ & $* 61.21 \mathrm{ab}$ & $85.52 \mathrm{ab}$ & $* 339.5 \mathrm{ab}$ & $778.8 \mathrm{ab}$ & $* 2.9 \mathrm{a}$ & $2.6 \mathrm{ab}$ \\
\hline $\mathrm{X} 10$ & $* 5.75 \mathrm{ab}$ & $10.27 \mathrm{ab}$ & $* 63.29 \mathrm{ab}$ & $77.48 \mathrm{ab}$ & $* 353.82 \mathrm{ab}$ & $760 \mathrm{ab}$ & $2.7 \mathrm{a}$ & $2.6 \mathrm{ab}$ \\
\hline Atlantic & $5.36 \mathrm{ab}$ & 7.73ab & $92.79 \mathrm{a}$ & $117.74 \mathrm{a}$ & $* 423.07 \mathrm{ab}$ & $904.8 \mathrm{ab}$ & $2.3 \mathrm{a}$ & $2.0 \mathrm{abc}$ \\
\hline $\mathrm{X} 1$ & $* 5.33 \mathrm{ab}$ & $8.94 \mathrm{ab}$ & $65.22 \mathrm{ab}$ & $72.00 \mathrm{ab}$ & *336.82ab & $585.4 \mathrm{ab}$ & $1.8 \mathrm{a}$ & $1.6 \mathrm{bc}$ \\
\hline $\mathrm{X} 7$ & $* 5.29 \mathrm{ab}$ & $9.59 \mathrm{ab}$ & $* 72.22 \mathrm{ab}$ & $89.57 \mathrm{ab}$ & $* 377.4 \mathrm{ab}$ & $854.1 \mathrm{ab}$ & $2.7 \mathrm{a}$ & $2.5 \mathrm{abc}$ \\
\hline Catucha & $5.20 \mathrm{ab}$ & $8.46 \mathrm{ab}$ & $57.65 \mathrm{ab}$ & $67.78 \mathrm{~b}$ & $* 300.2 \mathrm{ab}$ & $572.2 \mathrm{ab}$ & $2.0 \mathrm{a}$ & $1.3 \mathrm{bc}$ \\
\hline X6 & $* 5.01 \mathrm{ab}$ & $10.01 \mathrm{ab}$ & $* 49.12 \mathrm{ab}$ & $79.02 \mathrm{ab}$ & $* 268.6 \mathrm{ab}$ & $750.9 \mathrm{ab}$ & $2.5 \mathrm{a}$ & $2.6 \mathrm{ab}$ \\
\hline Macaca & $5.00 \mathrm{ab}$ & $12.00 \mathrm{ab}$ & $31.10 \mathrm{~b}$ & $50.08 \mathrm{~b}$ & $* 155.5 \mathrm{~b}$ & $586 a b$ & $2.0 \mathrm{a}$ & $2.0 \mathrm{abc}$ \\
\hline Hertha & *4.93ab & $10.06 \mathrm{ab}$ & $64.04 \mathrm{ab}$ & $66.53 \mathrm{~b}$ & $* 294.15 \mathrm{ab}$ & $667.6 \mathrm{ab}$ & $2.0 \mathrm{a}$ & $2.0 \mathrm{abc}$ \\
\hline Baronesa & $4.70 \mathrm{ab}$ & $5.90 \mathrm{~b}$ & $62.55 \mathrm{ab}$ & $85.74 \mathrm{ab}$ & $275.31 \mathrm{ab}$ & $507.2 \mathrm{~b}$ & $1.5 \mathrm{a}$ & $2.0 \mathrm{abc}$ \\
\hline $\mathrm{X} 3$ & *4.54ab & $9.95 \mathrm{ab}$ & $* 50.88 \mathrm{ab}$ & $70.91 \mathrm{ab}$ & *240.63ab & $689.1 \mathrm{ab}$ & $* 1.5 \mathrm{a}$ & $1.8 \mathrm{abc}$ \\
\hline $\mathrm{X} 5$ & $4.48 \mathrm{ab}$ & $9.07 \mathrm{ab}$ & $63.75 \mathrm{ab}$ & $83.37 \mathrm{ab}$ & 276.28ab & $710.3 \mathrm{ab}$ & $1.7 \mathrm{a}$ & $1.7 \mathrm{bc}$ \\
\hline Vivaldi & $4.16 \mathrm{ab}$ & $8.60 \mathrm{ab}$ & 71.94ab & $61.74 \mathrm{~b}$ & 291.0ab & $529.6 \mathrm{ab}$ & $1.3 \mathrm{a}$ & $2.0 \mathrm{abc}$ \\
\hline Monalisa & $* 4.05 \mathrm{~b}$ & $9.93 \mathrm{ab}$ & $55.10 \mathrm{ab}$ & $61.76 \mathrm{~b}$ & $* 221.65 \mathrm{ab}$ & $606.7 \mathrm{ab}$ & $1.3 \mathrm{a}$ & $1.0 \mathrm{c}$ \\
\hline Mean & 5.56 & 10.00 & 61.16 & 77.40 & 331.54 & 731.7 & 2.4 & 2.3 \\
\hline CV (\%) & 34.8 & 35.6 & 34.2 & 28.1 & 35.4 & 30.8 & 33.0 & 31.0 \\
\hline
\end{tabular}

Means followed by the same letter, in column, do not differ by the Tukey test at $5 \%$ of probability (médias seguidas da mesma letra minúscula nas colunas não diferem pelo teste Tukey, a $5 \%$ de probabilidade); $*$ Significativo a $5 \%$ de probabilidade, entre épocas (*significant at $5 \%$ of probability, between seasons). 


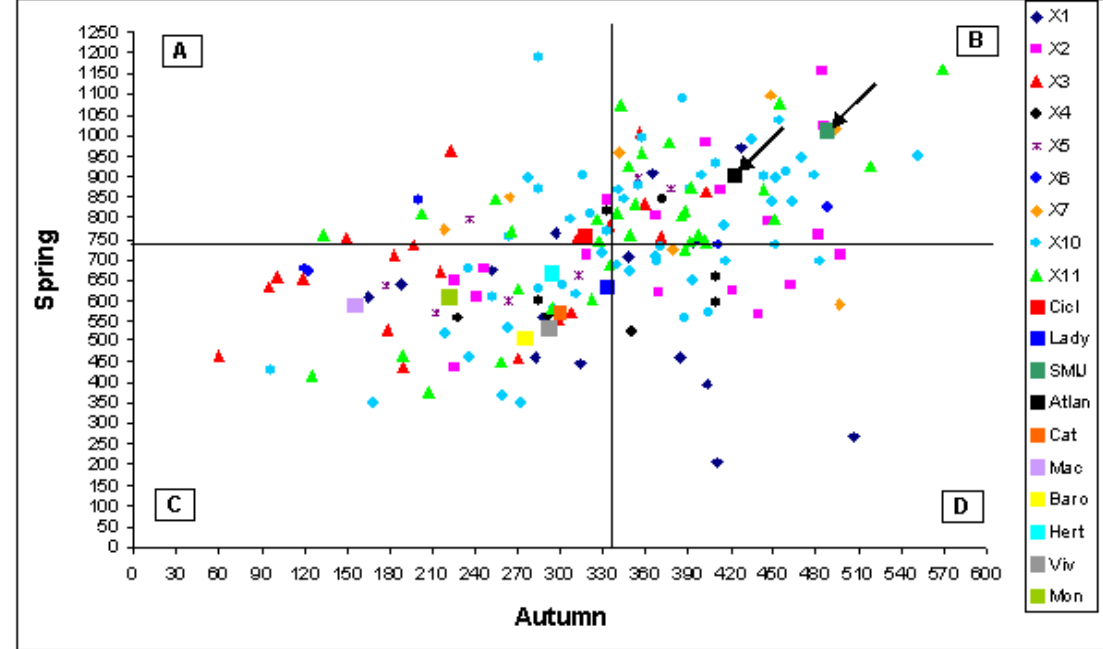

Figure 1. Yield/plant of clones and controls of families X1 (MonaXCiclâmen), X2 (L.RosetaXAtlan), X3 (AtlanXBaro), X4 (VivaXMacaca), X5 (VivaXBaro), X6 (MacacaXHertha), X7 (HerthaXAtlan), X10 (SMIJXAtlan) X11(AtlanXCatucha); X axis $=$ general mean autumn $=331.5 ; \mathrm{Y}$ axis $=$ general mean spring $=731.7$; squares $\mathrm{A}$ and $\mathrm{D}$ = show the clone $\mathrm{x}$ environment interaction; $\mathrm{B}=$ higher square, above of means, $\mathrm{C}=$ lower square, below of means (produtividade por planta das testemunhas e dos clones das famílias de batata X1 (MonalisaXCiclâmen), X2 (L.RosetaXAtlantic), X3 (AtlanticXBaronesa), X4 (VivaldiXMacaca), X5 (VivaldiXBaronesa), X6 (MacacaXHertha), X7 (HerthaXAtlantic), $\mathrm{X} 10$ (SMIJXAtlantic) X11 (AtlanticXCatucha); eixo $\mathrm{X}=$ média geral outono=331,5; eixo $\mathrm{Y}=$ média geral primavera $=731,7$; quadrantes $\mathrm{A}$ e $\mathrm{D}=$ mostram a interação clone $\mathrm{x}$ ambiente; $\mathrm{B}=$ quadrante superior, acima das médias; $\mathrm{C}=$ quadrante inferior, abaixo das médias). Passo Fundo, UPF, 2006/2007.

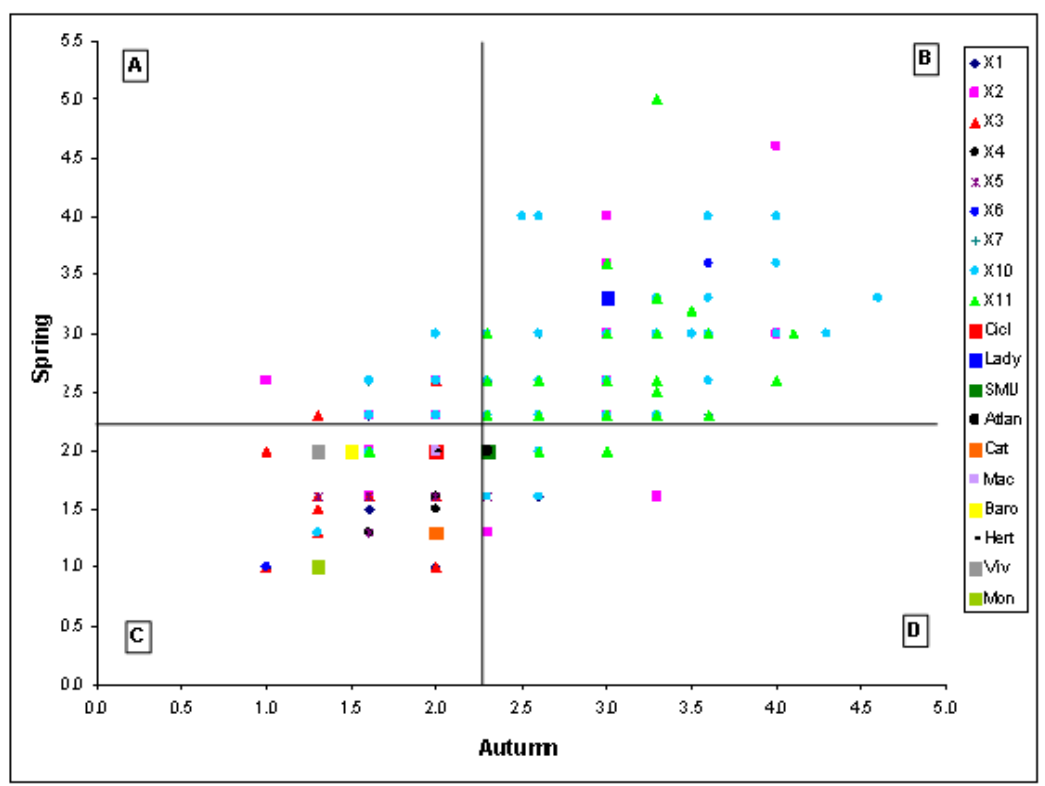

Figure 2. Deep eyes for clones and controls of families X1 (MonaXCiclâmen), X2 (L.RosetaXAtlan), X3 (AtlanXBaro), X4 (VivaXMacaca), X5 (VivaXBaro), X6 (MacacaXHertha), X7 (HerthaXAtlan), X10 (SMIJXAtlan) X11 (AtlanXCatucha); X axis $=$ general mean autumn $=2.4 ; \mathrm{Y}$ axis $=$ general mean spring $=2.3$; square $\mathrm{A}$ and $\mathrm{D}$ = show the clone $\mathrm{x}$ environment interaction; $\mathrm{B}=$ higher square, shallow eyes; $\mathrm{C}=$ lower square, deep eyes (profundidade dos olhos das testemunhas e dos clones das famílias de batata X1 (MonalisaXCiclâmen), X2 (L.RosetaXAtlantic), X3 (AtlanticXBaronesa), X4 (VivaldiXMacaca), X5 (VivaldiXBaronesa), X6 (MacacaXHertha), X7 (HerthaXAtlantic), X10 (SMIJXAtlantic) X11 (AtlanticXCatucha); eixo $\mathrm{X}=$ média geral outono=2,4; eixo $\mathrm{Y}=$ média geral primavera $=2,3$; quadrantes $\mathrm{Ae} \mathrm{D}=$ mostram a interação clone $\mathrm{x}$ ambiente; $\mathrm{C}=$ quadrante superior, olhos mais rasos; B= quadrante inferior, olhos mais profundos). Passo Fundo, UPF, 2006/2007. the cultivar Baronesa and the clone SMIJ461-1. Considering the average of the two seasons, the control cultivars with the highest fresh weight of tubers were Atlantic and SMIJ461-1 and with the lowest fresh weight were Macaca and Ciclamen. Among the families, no statistical differences were observed to average fresh weight of tubers. The highest means among families were observed for X7 (Hertha x Atlantic), X11 (Catucha X Atlantic) and X10 (SMIJ461-1 x Atlantic), suggesting a greater influence of the parent 'Atlantic' for this character. The X4 family, which has the cultivar Macaca as one of the parents (Vivaldi x Macaca) presented the lowest fresh weight for tubers, which can be explained by the lower average observed in this cultivar for this character. These observations indicate that families with higher average fresh weight of tubers and greater number of tubers per plant can be obtained if appropriate parents were used.

The average yield per plant in the spring was $731.7 \mathrm{~g}$ representing more than twice the productivity obtained in the autumn, which was $331.54 \mathrm{~g}$ (Table 1). Lower average productivity of tubers in the autumn season was also observed by Andreu (2005). The yield of tubers has a strong relation with the cycle length in days and the highest yields are obtained in cropping of late winter and early spring, which is the recommended period for the main potato season (Matielo et al., 2005). The control treatment SMIJ4611 presented the best performance in the two cropping seasons. However, this treatment presented significant difference in comparison to 'Macaca' only in the autumn and in comparison to 'Baronesa' only in the spring. The families did not present significant differences among each other in the two cropping seasons. This difficulty to detect statistical differences between the families was probably due to genetic variability within families, which in many cases may be higher than the variability among families. This is due to the tetrasomy segregation of the tetraploid potato. In addition, the families were composed of few clones, mostly half-sib progenies.

The trait depth of eyes did not vary 
Table 2. Means of dry matter content and chips color $\left(\mathrm{L}^{*}\right)$ of nine families and ten controls, in autumn and spring growing seasons (médias de teor de massa seca e coloração dos chips ( $\left.\mathrm{L}^{*}\right)$ nas nove famílias e dez testemunhas, no cultivo de outono e primavera). Passo Fundo, UPF, 2006/2007.

\begin{tabular}{|c|c|c|c|c|}
\hline \multirow{2}{*}{ Families and clones } & \multicolumn{2}{|c|}{ Dry matter } & \multicolumn{2}{|c|}{ Color $\mathrm{L}^{* 2}$} \\
\hline & Autumn & Spring & Autumn & Spring \\
\hline Atlantic & $* 25.9 a^{1}$ & 20.3 cde & $* 58.9 \mathrm{abc}$ & $52.9 \mathrm{ab}$ \\
\hline X11 & $* 25.7 \mathrm{~A}$ & $22.8 \mathrm{abc}$ & *43.9 bcde & $54.8 \mathrm{ab}$ \\
\hline X6 & $* 25.1 \mathrm{Ab}$ & 20.6 cde & $* 30.5 \quad \mathrm{e}$ & $58.9 \mathrm{a}$ \\
\hline Lady Roseta & $24.4 \mathrm{Abc}$ & $25.6 \mathrm{abc}$ & $54.2 \mathrm{abc}$ & $49.2 \mathrm{ab}$ \\
\hline $\mathrm{X} 10$ & $* 24.4 \mathrm{Abc}$ & $22.0 \mathrm{abcd}$ & $* 49.7 \mathrm{abc}$ & $55.4 \mathrm{ab}$ \\
\hline $\mathrm{X} 7$ & $* 24.1 \mathrm{Abc}$ & 21.6 bcde & $48.7 \mathrm{abcd}$ & $53.0 \mathrm{ab}$ \\
\hline Macaca & $* 23.6 \mathrm{Abcd}$ & 20.5 cde & $* 51.3 \mathrm{abc}$ & $58.8 \mathrm{a}$ \\
\hline $\mathrm{X} 2$ & *23.6 Abcd & 20.9 bcde & $* 61.3 \mathrm{ab}$ & $58.0 \mathrm{a}$ \\
\hline Ciclamen & *23.4 Abcd & $26.6 \mathrm{a}$ & $* 61.6 \mathrm{a}$ & $51.6 \mathrm{ab}$ \\
\hline SMIJ461-1 & $* 23.0 \mathrm{Abcd}$ & 21.9 abcde & 43.3 cde & $56.3 \mathrm{ab}$ \\
\hline Baronesa & *22.9 Abcde & $17.3 \mathrm{de}$ & $59.0 \mathrm{abc}$ & $55.7 \mathrm{ab}$ \\
\hline Catucha & 22.9 Abcde & 20.3 cde & $45.4 \mathrm{abcde}$ & $44.1 \mathrm{~b}$ \\
\hline Hertha & *21.0 Abcde & $18.3 \mathrm{cde}$ & $52.7 \mathrm{abc}$ & $50.9 \mathrm{ab}$ \\
\hline $\mathrm{X} 4$ & *20.9 Abcde & 18.2 cde & *45.1 abcde & $53.3 \mathrm{ab}$ \\
\hline $\mathrm{X} 3$ & *20.6 bcde & $17.7 \mathrm{de}$ & $52.5 \mathrm{abc}$ & $53.2 \mathrm{ab}$ \\
\hline $\mathrm{X} 5$ & 20.5 bcde & 19.2 cde & *31.6 de & $53.8 \mathrm{ab}$ \\
\hline $\mathrm{X} 1$ & *19.8 Cde & $17.1 \mathrm{e}$ & $55.0 \mathrm{abc}$ & $55.5 \mathrm{ab}$ \\
\hline Vivaldi & $19.0 \mathrm{De}$ & $18.5 \mathrm{cde}$ & $51.4 \mathrm{abc}$ & $57.0 \mathrm{a}$ \\
\hline Monalisa & $* 18.0 \quad \mathrm{E}$ & $17.5 \mathrm{de}$ & *41.5 cde & $52.7 \mathrm{ab}$ \\
\hline Média & 23.3 & 20.7 & 49.2 & 55.0 \\
\hline $\mathrm{CV}(\%)$ & 8.0 & 8.6 & 16.3 & 10.6 \\
\hline
\end{tabular}

${ }^{1}$ Means followed by the same letter in column, do not differ by the Tukey test at $5 \%$ of probability (médias seguidas da mesma letra nas colunas não diferem pelo teste Tukey, a 5\% de probabilidade); ${ }^{*}$ Significant at $5 \%$ of probability, between seasons (significativo a $5 \%$ de probabilidade, entre épocas).

in the two growing seasons, and the overall average was 2.4 and 2.3 (semisuperficial to medium depth of eyes) to autumn and spring, respectively (Table 1). Andreu (2005) also noted consistency in relation to the depth of the eyes in the cultivation of autumn and spring. In the autumn season no differences among treatments were detected. In the spring, the control treatments 'Monalisa' and 'Catucha' and the families X4, X1 and X5 were superior to the cultivar Lady Roseta.

Considering the four agronomic traits in the two growing seasons, the clone SMIJ461-1 was the control treatment with the best performance, particularly for the yield traits. 'Ciclamen' was the control treatment that presented the highest number of tubers, but on the other hand, this cultivar and the cultivar Macaca presented low fresh mass of tubers.
The effect of the interaction genotype $\mathrm{x}$ environment, in the two growing seasons, on the performance of the clones of different families for the traits yield per plant and depth of eyes, can be better visualized in the scatter plots.

For yield per plant (Figure 1), the X11 family can be highlighted, since $52.9 \%$ of the clones showed productivity above the average of the two seasons (quadrant B). The clones of the families X4 and X1 showed poor performance in the two seasons. The control treatments SMIJ461-1 and Atlantic (highlighted by arrows in the figure) showed productivity higher than the two averages (quadrant B) and 'Catucha', 'Macaca', 'Baronesa', 'Hertha', 'Vivaldi' and 'Monalisa' were placed in the lower quadrant (C). 'Ciclamen' and 'Lady Roseta' were placed close to the axes of the average values.
The character depth of eyes showed a low genotype $\mathrm{x}$ environment interaction (Figure 2). The clones of the families X1 ('Monalisa' x 'Ciclamen'), X3 ('Atlantic' $x$ 'Baronesa'), X4 ('Vivaldi' $\mathrm{x}$ 'Macaca') and X5 ('Vivaldi' $x$ 'Baronesa') presented the most superficial eyes in the two seasons (quadrant $\mathrm{C}$ ), and no clones from these families were placed in the quadrant of higher depth (B). The families X11 ('Catucha' $\mathrm{x}$ 'Atlantic') and X10 (SMIJ461-1 x 'Atlantic') presented the highest percentage of clones with greater depth of the eyes, $50 \%$ and $40.7 \%$, respectively. All the control treatments except for 'Lady Roseta' were placed in the upper quadrant (C).

Regarding the traits related to processing quality, dry matter content and chip color $\left(\mathrm{L}^{*}\right)$, differences for seasons, families and control treatments and for the interaction among them were 
significant.

The highest percentage of dry mass was obtained in the autumn and the highest average chip color $\left(\mathrm{L}^{*}\right)$ occurred in the spring cultivation (Table 2). The overall mean for dry weight was $23.3 \%$ in the autumn and $20.7 \%$ in the spring. The lower content of dry mass, registered in the spring, can be explained by the high temperatures observed at the end of the cycle. The dry matter production is faster at $20^{\circ} \mathrm{C}$, when assimilation is high and respiration is low. Average temperatures of 25 to $30^{\circ} \mathrm{C}$ are very unfavorable to the production of dry matter, and the production obtained at $30^{\circ} \mathrm{C}$ is half that obtained at $20^{\circ} \mathrm{C}$ and lower than at $10^{\circ} \mathrm{C}$ (Van der Zaag apud Souza, 2003). These data are in agreement with Rodrigues \& Pereira (2003), who observed higher means of dry weight in potato clones grown in the autumn. On the other hand, Müller et al. (2009) observed in potato clones grown in the spring dry matter content of $2.56 \%$ on average, value higher than the clones grown in the autumn.

Regardless of the growing season, some cultivars such as Ciclamen, Lady Roseta and Atlantic presented an average dry matter content considerably high. Unlike them, 'Vivaldi' and 'Monalisa' presented levels below 20\%. Dry matter content above $20 \%$ is considered good for processing, providing products with higher yield and reducing fat absorption during frying (Capezio et al. apud Freitas et al., 2006). Families X3, $\mathrm{X} 5, \mathrm{X} 1$ and the cultivars Vivaldi and Monalisa presented the lowest levels of dry matter in the autumn, differing from the other families and cultivars. 'Monalisa' and 'Baronesa' presented the lowest dry matter content in the spring (Table 2).

The higher content values of dry matter in the spring were obtained with the cultivar Ciclamen, which did not differ from 'Lady Roseta', SMIJ461-1 and the families X11 and X10 (Table 2). Considering the two seasons, the families with the highest averages for dry weight were X11 and X10, whose parents were 'Atlantic' $\mathrm{X}$ 'Catucha' and 'Atlantic' x SMIJ461-1, respectively. The cultivar Atlantic presented high levels of dry matter and transmitted this characteristic to the progeny, as can be seen in the crossings with 'Catucha' and SMIJ461-1. The family X1, descendant from the crossing between 'Monalisa' and 'Ciclamen', was the one with the lowest dry matter content in both seasons.

The lower content of dry matter observed in the spring can also be explained by the storage of tubers at room temperature. Storage at high temperature accelerates the physiological aging by increasing respiration and metabolism, with higher fresh mass loss and the rapid degradation of the tuber reserves (Bisognin et al., 2006).

For the chip color, the average value of $\mathrm{L}^{*}$ was higher in the spring, which means a lighter general coloration in this growing season, although some families and genitors has not presented differences among seasons (Table 2). These data are in agreement with those obtained by Freitas et al. (2006), who also reported lighter coloration of chips in the spring. The family X2 ('Atlantic' $\mathrm{x}$ 'Lady Roseta') presented the highest mean for $\mathrm{L}^{*}$, considering the two growing seasons. Among the cultivars, 'Baronesa', 'Ciclamen' and 'Atlantic', presented the most light coloration in the two growing seasons.

The correlation coefficients between the two cropping seasons were significant for all traits. For yield traits, the number of tubers per plant showed the highest correlation (0.45), followed by productivity per plant $(0.32)$ and average tuber fresh weight (0.27). Depth of eyes showed a correlation of 0.54. Andreu (2005) observed that depth of the eyes, skin texture and shape were highly correlated between periods of cultivation, and they were traits with little interaction between clones and growing seasons. For processing quality, the highest correlation (0.58) was observed in the dry matter content, and Rodrigues \& Pereira (2003) found a somewhat lower correlation (0.40) for this trait, between autumn and spring.

Among the clonal families, clones that express better characteristics in the two cropping seasons were identified. The expression of the genetic potential for traits related to production is maximized in the spring due to the better environmental conditions that favor the expression of the genotype. The traits depth of eyes and dry mass can be selected either in the autumn and spring, since they present a high correlation between the two cropping seasons.

\section{REFERENCES}

ANDREU MA. 2005. Associação entre características agronômicas da batata nos plantios de primavera e outono no Rio Grande do Sul. Ciência e Agrotecnologia 29: 925-929.

ANDREU MA. 2006. Avanços no melhoramento genético para qualidade de processamento da batata. Batata Show 6:16.

AOAC., 1980. Official methods of analysis, $13^{\text {th }}$ ed. In: HORWITZ W; LATIMER G (eds). Association of official analytical chemists. Washington DC. p. 376-384.

BEARZOTI E; BRASIL CA; PINTO P; OLIVEIRA MS 1997. Comparação entre métodos estatísticos na avaliação de clones em um programa de melhoramento de batata. Pesquisa Agropecuária Brasileira 32: $877-$ 884.

BISOGNIN DA. 1996. Recomendações técnicas para o cultivo da batata no Rio Grande do Sul e Santa Catarina. Santa Maria: UFSM. 64p.

BISOGNIN DA; FREITAS ST; PEREIRA EIP; BANDINELLI MG. 2006. Envelhecimento fisiológico de tubérculos de batata. Informe técnico, UFSM nº5/2006. Disponível em http://coralx.ufsm.br/batata/tabfig/EnvelFisio. pdf. Acessado em 11 de outubro de 2009.

BISOGNIN DA. 2006. Pesquisa científica e tecnológica desenvolvidas em batata na Universidade Federal de Santa Maria. In: REUNIÃO TÉCNICA DE PESQUISA E EXTENSÃO DA CULTURA DA BATATA DA REGIÃO SUL, 9. Anais... Santa Maria: UFSM. p. 109-130.

BISOGNIN DA; STRECK NA. 2009. Desenvolvimento e manejo das plantas para alta produtividade e qualidade da batata. Itapetininga: Associação Brasileira da Batata. Publicação Técnica. 32p.

COELHO AHR; VILELA ER; CHAGAS SJR. 1999. Qualidade de batata (Solanum tuberosum L.) para fritura, em função dos níveis de açúcares redutores e amido, durante o armazenamento refrigerado e à temperatura ambiente com a atmosfera modificada. Ciência e Agrotecnologia 23: 899-910.

DALE MFB; MACKAY GR. 1994. Inheritance of table and processing quality. In: BRADSHAW JE; MACKAY GR (eds). Potato genetics. Wallingford:CAB International. p. 285-315.

FREITAS ST; BISOGNIN DA; GÓMEZ ACS; SAUTTER CK; COSTA LC; RAMPELOTTO, MV. 2006. Qualidade para processamento de clones de batata cultivados durante a primavera e outono no Rio Grande do Sul. Ciência Rural 36: $80-85$.

MATIELO FLP; STRECK NA; HELDWEIN AB; BISOGNIN DA; HELDWEIN AB; LAGO I. 
2005. Filocrono da planta de batata cultivar Asterix em diferentes épocas de plantio. Revista Brasileira de Agrometeorologia 13: 367-374.

MÜLLER DR; BISOGNIN DA; ANDRIOLO JL; MORIN JUNIOR GR; GNOCATO FS. 2009. Expressão dos caracteres e seleção de clones de batata nas condições de cultivo de primavera e outono. Ciência Rural 39: 1327-1334.

PEREIRAAS. 2003. Melhoramento Genético. In: PEREIRA AS; DANIELS J. (eds) $O$ cultivo da batata na região sul do Brasil. Brasília:
Embrapa Informação Tecnológica/Embrapa Clima Temperado. p.105-124.

POPP P. 2000. Industrialização da batata no Brasil. In: WORKSHOP BRASILEIRO DE PESQUISA EM MELHORAMENTO DE BATATA, 1996. Anais... Londrina, PR. Brasília: EMBRAPA Hortaliças. p.35.

RODRIGUES AFS; PEREIRA AS. 2003. Correlações inter e intragerações e herdabilidade de cor de chips, matéria seca e produção em batata. Pesquisa Agropecuária
Brasileira 38: 599-604.

SOUZA ZS. 2003. Ecofisiologia. In: PEREIRA AS; DANIELS J. O cultivo da batata na região sul do Brasil. Brasília: Embrapa Informação Tecnológica. p. 80-104.

ZORZELLA CA; VENDRUSCOLO JL; TREPTOW RO. 2003. Qualidade sensorial de "chips" de diferentes genótipos de batatas (Solanum tuberosum L.), cultivos de primavera e outono no Rio Grande do Sul. Revista Brasileira de Agrociência 9: 57-63. 